\title{
Serum levels of adipokines and cytokines in psoriasis patients: a systematic review and meta-analysis
}

\author{
Fan Bai ${ }^{1}$, Wen Zheng ${ }^{1}$, Yan Dong ${ }^{1}$, Juan Wang ${ }^{1}$, Malgorzata A. Garstka ${ }^{1}$, Ruilian Li ${ }^{1}$, \\ Jingang $\mathrm{An}^{1}$ and Huiqun $\mathrm{Ma}^{1}$ \\ ${ }^{1}$ The Second Affiliated Hospital of Xi'an Jiaotong University, Xi'an, China
}

Correspondence to: Huiqun Ma, email: mahuiqun@mail.xjtu.edu.cn

Keywords: psoriasis, serum, adipokine, cytokine, meta-analysis

Received: April 27, $2017 \quad$ Accepted: October 04, 2017

Published: November 01, 2017

Copyright: Bai et al. This is an open-access article distributed under the terms of the Creative Commons Attribution License 3.0 (CC BY 3.0), which permits unrestricted use, distribution, and reproduction in any medium, provided the original author and source are credited.

\section{ABSTRACT}

Purpose: To evaluate the association of serum levels of adipokines and cytokines with psoriasis.

Materials and Methods: A comprehensive literature search was performed in PubMed, ScienceDirect and Web of Science for the available relevant studies published before December 1, 2016. Differences in serum marker levels between patients and controls were pooled as standardized mean differences (SMDs) with $95 \%$ confidence interval to combine the effect estimations. We also conducted stratified analysis, meta-regression analysis and sensitivity analysis.

Results: Sixty-three studies containing 2876 psoriasis patients and 2237 healthy controls were included in this meta-analysis. The pooled serum levels of TNF- $a$, IFN- $y$, IL-2, IL-6, IL-8, IL-18, IL-22, chemerin, lipocalin-2, resistin, sE-selectin, fibrinogen and $\mathrm{C} 3$ were higher in psoriasis patients compared with healthy controls (all $P<$ $0.05)$. In contrast, adiponectin levels were lower. Serum levels of IL-1 $\beta$, IL-4, IL10, IL-12, IL-17, IL-21, IL-23, visfatin and omentin were not significantly different between psoriasis patients and controls (all $P>0.05$ ). However, increased serum levels of IL-17 correlated with psoriasis in men. For other biomarkers, age, gender and psoriasis area and severity index did not explain the differences in effect size between the studies.

Conclusions: Serum levels of TNF-a, IFN-Y, IL-2, IL-6, IL-8, IL-18, IL-22, chemerin, lipocalin-2, resistin, sE-selectin, fibrinogen, complement 3, and adiponectin correlate with psoriasis and can be used as potential biomarkers for psoriasis and response to the treatment. Future studies are needed to identify additional players involved in the pathogenesis of psoriasis and to fully decipher the underlying mechanism.

\section{INTRODUCTION}

Psoriasis is a serious, chronic, immune-mediated, hyperproliferative, and inflammatory skin disease of varying severity, which may induce itchy or painful lesions and negatively impact quality of life $[1,2]$. The prevalence of this disease ranges from $0.51 \%$ to $11.43 \%$ in different countries [3].

The genetic, immunological and environmental factors contribute to the pathogenesis of psoriasis. However, its precise etiology is not yet fully elucidated. The pathological mechanism in psoriasis involves cutaneous inflammation and keratinocytes hyperproliferation induced by an inflammatory cascade in dermis involving innate and adaptive immune cells. White adipose tissue located beneath the skin may contribute to the cutaneous inflammation by secreting adipokines and cytokines. The abnormal cutaneous and systemic expression of adipokines and cytokines could influence the activation, proliferation and differentiation of keratinocytes as well as immune cells contributing to the development of psoriatic lesions [4, 5]. Although the majority of inflammatory makers produced by adipose tissue and keratinocytes remains in the tissue, a small 
proportion of these biomarkers could also be identified in the systemic circulation [6]. These biomarkers measured in blood could be used to evaluate the disease severity and to monitor response to the treatment [7]. Recently, several studies have investigated the correlation of serum levels of adipokines and cytokines with psoriasis development and severity, but the results are controversial [8-12]. Moreover, some of these studies did not explore the effect of potential confounding factors, e.g. age, gender, ethnicity, on the association of adipokines and cytokines with psoriasis.

Therefore, we perform a meta-analysis of all eligible studies to compare the serum levels of 23 markers: tumour necrosis factor (TNF)- $\alpha$, interferon (IFN)- $\gamma$, interleukin (IL)-1 $\beta$, IL-2, IL-4, IL-6, IL-8, IL-10, IL-12, IL-17, IL18, IL-21, IL-22, IL-23, adiponectin, chemerin, omentin, visfatin, lipocalin-2, resistin, soluble E-selectin ( $\mathrm{sE}$ selectin), fibrinogen, and complement 3 (C3), between psoriasis patients and healthy controls. Furthermore, we evaluate whether the strength of the association of these serum markers and risk of psoriasis varies by age, gender, ethnicity, psoriasis area and severity index (PASI), or psoriasis type.

\section{RESULTS}

In total, 8412 publications matching the search criteria were identified. After the removal of duplicates, titles and abstracts of 7663 publications were screened, and 159 publications were determined to be potentially eligible. Based on the inclusion and excluding criteria, 63 articles were included in this meta-analysis (Figure 1) [870]. The characteristics of the included studies are shown in Supplementary Table 2.

Our study included 2876 psoriasis patients and 2237 healthy subjects. Among 63 studies, fifty-nine studies were case-control studies and four were cross-sectional studies, reporting the relationship between serum biomarker levels and psoriasis. Fifty-four studies were conducted in Caucasian populations and nine in Asian populations. The average age ranged from 23.0 to 60.8 in patient groups and 65.1 to 77.0 in control groups. A Psoriasis Area and Severity Index, PASI, was reported in $68.5 \%$ studies, with overall mean PASI $12.5 \pm 7.8$, and the average score from 5.2 to 26.7. Enzyme linked immunosorbent assay (ELISA) results were reported in 42 studies.

\section{Serum profile of pro-inflammatory cytokines in psoriasis patients}

The serum levels of thirteen pro-inflammatory cytokines: TNF- $\alpha$, IFN- $\gamma$, IL-1 $\beta$, IL-2, IL-4, IL-6, IL-8, IL12, IL-17, IL-18, IL-21, IL-22, and IL-23, were evaluated in this meta-analysis. The mean serum levels of seven of them: TNF- $\alpha$, IFN- $\gamma$, IL-2, IL-6, IL-8, IL-18, and IL-22, were significantly higher in psoriasis patients than those in controls (Figure 2, Supplementary Table 3, Supplementary Figures $1-7$; TNF- $\alpha$ : $\mathrm{SMD}=1.35,95 \% \mathrm{CI} 0.82$ to 1.88 ; IFN- $\gamma: \mathrm{SMD}=1.84,95 \%$ CI 0.70 to 2.97 ; IL-2: SMD = $0.77,95 \%$ CI 0.36 to 1.19 ; IL-6: $\mathrm{SMD}=1.32,95 \%$ CI 0.69 to 1.95 ; IL-8: $\mathrm{SMD}=1.59,95 \%$ CI 0.87 to 2.31 ; IL-18: $\mathrm{SMD}=1.62,95 \%$ CI 1.22 to 2.03 ; IL-22: SMD = $0.84,95 \% \mathrm{CI} 0.21$ to 1.46$)$. The serum levels of remaining six inflammatory cytokines (IL-1 $\beta$, IL-4, IL-12, IL-17, IL-21, and IL-23) did not show a significant difference between the psoriasis patients and control groups (Figure 2 , Supplementary Figures 8-13; IL-1 $\beta$ : SMD $=0.06,95 \%$ CI -0.59 to 0.71 ; IL-4: $\mathrm{SMD}=0.25,95 \% \mathrm{CI}-0.21$ to 0.70 ; IL-12: $\mathrm{SMD}=0.22,95 \% \mathrm{CI}-0.55$ to 1.00 ; IL-17: $\mathrm{SMD}=$ $0.43,95 \% \mathrm{CI}-0.16$ to 1.03 ; IL-21: $\mathrm{SMD}=1.55,95 \% \mathrm{CI}$ -0.21 to 3.31 ; IL-23: $\mathrm{SMD}=0.66,95 \% \mathrm{CI}-0.25$ to 1.58 ). Meta-regression involving adjustment for gender observed that the higher the percentage of men in the study, the larger the difference in IL-17 between psoriasis patients and healthy controls Figure 3, Supplementary Table 3; slope: $-17.34,95 \%$ CI -26.60 to $-8.07 ; P=0.02$ ). Moreover, after adjustment for ethnicity, higher serum levels of IL-17 were associated with psoriasis in Asians, but not in Caucasians (Supplementary Table 1, Asians: SMD $=0.54,95 \%$ CI -0.44 to $1.51, \mathrm{I}^{2}=96.1 \%$; Caucasians: $\mathrm{SMD}=0.27,95 \%$ CI 0.04 to $0.49, I^{2}=0 \%$ ). No difference between Asians and Caucasians was observed for the correlation of other inflammatory cytokines with psoriasis. The increased serum levels of IL-2 were associated with other types of psoriasis, but not with psoriasis vulgaris (Supplementary Table 1, Others: $\mathrm{SMD}=0.89,95 \%$ CI 0.24 to $1.52, \mathrm{I}^{2}=$ $81.9 \%$; Psoriasis vulgaris: $\mathrm{SMD}=0.57,95 \%$ CI 0.16 to $0.98, \mathrm{I}^{2}=0 \%$ ). However due to the low number of included studies, such correlation needs to be further investigated. Adjustments for age and study quality score did not alter the results (Supplementary Table 3).

\section{Serum profile of anti-inflammatory cytokines in psoriasis patients}

One anti-inflammatory serum biomarker IL-10 was assessed in our meta-analysis. We found no significant difference of IL-10 serum concentrations between the psoriatic patients and healthy controls (Figure 2; Supplementary Figure 14; SMD $=-0.56,95 \%$ CI -2.22 to 1.10) [123]. The meta-regression by age, gender, PASI or study quality score and the stratified analysis across ethnicity, study design and psoriasis type showed that these factors did not significantly affect the results (Supplementary Table 3).

\section{Serum profile of other soluble factors}

We also evaluated the relation of sE-selectin, fibrinogen, and $\mathrm{C} 3$ serum levels to psoriasis and found they were increased in psoriasis patients (Figure 2, Supplementary Figures 15-17, sE-selectin: SMD $=1.90$, 
95\% CI 1.07 to 2.74; Fibrinogen: $\mathrm{SMD}=0.98,95 \% \mathrm{CI}$ 0.53 to $1.42 ; \mathrm{C} 3: \mathrm{SMD}=0.62,95 \% \mathrm{CI} 0.03$ to 1.21 ). The results of meta-regression for gender showed a borderline association of the higher fibrinogen serum level with the higher percentage of men in the study (Supplementary Table 3, slope: $-4.01,95 \%$ CI -8.34 to $0.31 ; P=0.06$ ). The results of subgroup analysis by age, ethnicity, study design, and psoriasis type did not show the significant differences (Supplementary Table 3, Supplementary Table 1).

\section{Serum profile of adipokines}

Subsequently, we evaluated the association between serum levels of adipokines (adiponectin, omentin, chemerin, visfatin, lipocalin-2, and resistin) and psoriasis. The mean value of adiponectin serum levels was significantly lower, whereas the mean values of lipocalin-2, chemerin and resistin serum levels were significantly higher in psoriasis patients than that in healthy controls (Figure 2; Supplementary Figures 18-21, Adiponectin: $\mathrm{SMD}=-0.90,95 \% \mathrm{CI}-1.78$ to -0.02 ; Lipocalin-2: $\mathrm{SMD}=$
0.74, $95 \%$ CI 0.46 to 1.02 ; Chemerin: $\mathrm{SMD}=3.55,95 \%$ CI 0.86 to 6.24; Resistin: $\mathrm{SMD}=1.97,95 \%$ CI 0.58 to 3.37). No significant differences in serum levels of visfatin and omentin were observed between the psoriasis patients and healthy controls (Figure 2, Supplementary Figure 22, Supplementary Figure 23, Visfatin: SMD $=0.43,95 \%$ CI -0.25 to 1.10 ; Omentin: $\mathrm{SMD}=0.89,95 \% \mathrm{CI}-1.53$ to 3.31 ;). The results of subgroup analysis by ethnicity revealed that the lower serum levels of adiponectin were observed in Caucasians, than in Asians (Supplementary Table 1, Caucasians: SMD $=-1.17,95 \% \mathrm{CI}-2.22$ to -0.12 ; $\mathrm{I}^{2}=97.30 \%$; Asians: $\mathrm{SMD}=0.03,95 \% \mathrm{CI}-1.64$ to 1.69 ; $\mathrm{I}^{2}=94.10 \%$ ). Moreover, no association with psoriasis was found in serum levels of lipocalin-2 in Caucasians (Supplementary Table 1, Caucasians: SMD $=0.85$, 95\% CI 0.58 to $1.12, \mathrm{I}^{2}=0$ ). Subgroup analysis by psoriasis type found significant differences in adiponectin serum levels between the psoriasis patients and healthy controls (Supplementary Table 1, Psoriasis vulgaris: SMD $=-1.29$, $95 \%$ CI -2.55 to $-0.03 ; \mathrm{I}^{2}=97.7 \%$, Others: $\mathrm{SMD}=-0.15$, $95 \% \mathrm{CI}-1.14$ to $0.84, \mathrm{I}^{2}=90.7 \%$ ). The subgroup and meta-regression analyses found that age, gender, PASI,

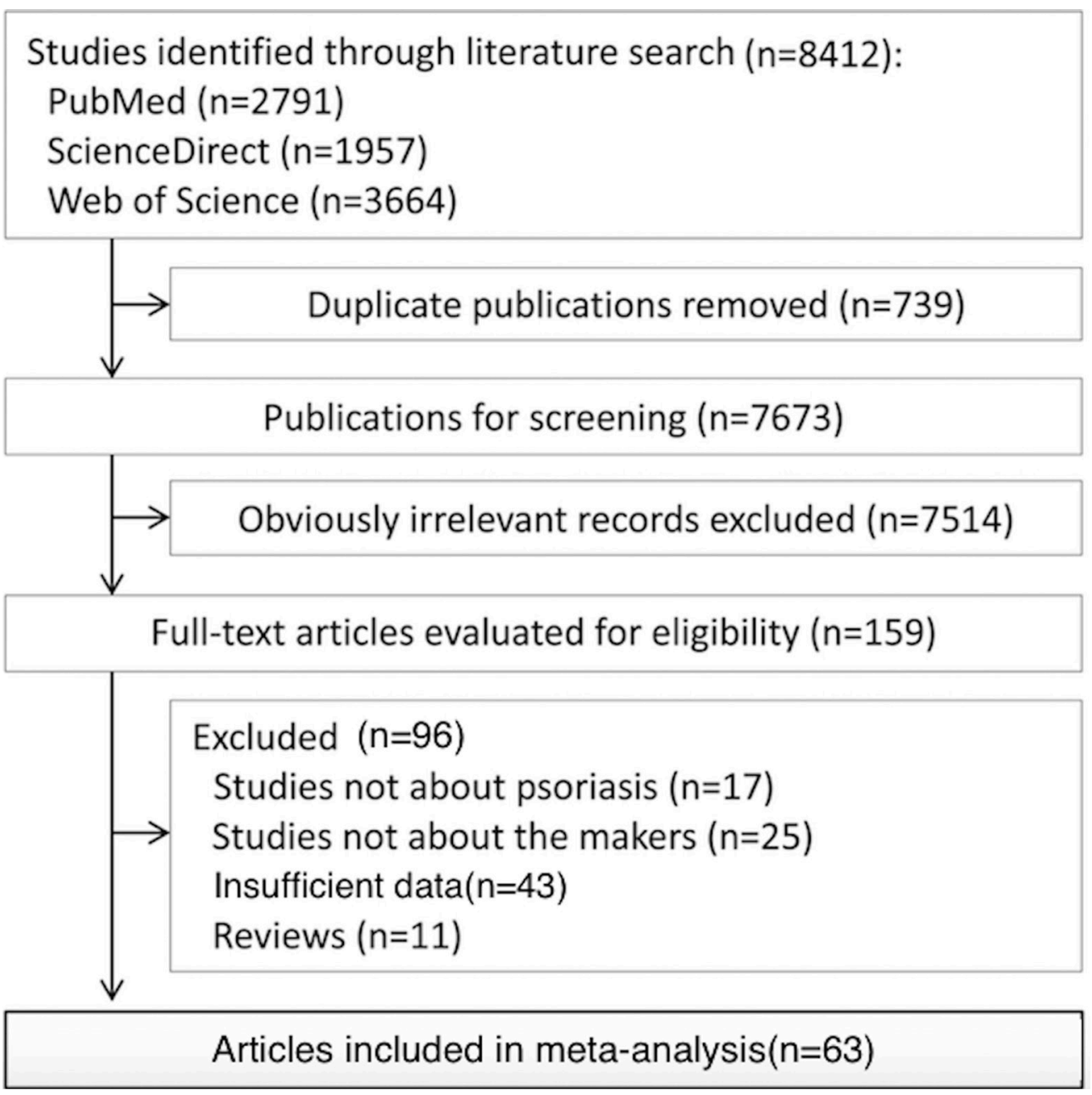

Figure 1: Flowchart for the selection of eligible studies. 
and study quality score did not significantly affect the results (Supplementary Table 3).

\section{Sensitivity analysis and publication bias}

The sensitivity analysis revealed that the results remained stable and reliable. The Begg's funnel plot and Egger's test found no evidence of publication bias (Supplementary Table 3).

\section{DISCUSSION}

Our meta-analysis showed systemic inflammation in psoriasis patients compared with healthy individuals, with 13 of 23 analysed pro-inflammatory soluble factors (TNF- $\alpha$, IFN- $\gamma$, sE-selectin, IL-2, IL-6, IL-8, IL-18, IL-22, chemerin, lipocalin-2, resistin, fibrinogen and C3) being increased and one anti-inflammatory marker (adiponectin) being decreased in psoriasis patients. Serum levels of IL$1 \beta$, IL-4, IL-10, IL-12, IL-17, IL-21, IL-23, visfatin and omentin were not significantly different in patients and controls. The meta-regression by gender observed higher serum levels of IL-17 between psoriasis patients and controls. For other biomarkers, age, gender, study quality and PASI do not explain the differences in effect size between the studies.

Adipose tissue is located under the skin and contains adipocytes, a variety of immune cells and other cells including the vascular endothelial cells. In recent years, adipose tissue has been recognized as a major endocrine organ producing bioactive mediators, such as adipokines (including adiponectin or resistin), chemokine and cytokines (including TNF- $\alpha$, IL-6 and IL-8). Given adipose tissue properties and its widespread localization, it was suggested to affect skin immune system and contribute to the pathogenesis of psoriasis $[20,71,72$, 75]. In the current meta analysis we compared the levels of adipokines (adiponectin, omentin, chemerin, visfatin, lipocalin-2 and resistin), circulating cytokines (TNF- $\alpha$, IFN- $\gamma$, IL-1 $\beta$, IL-2, IL-4, IL-6, IL-8, IL-10, IL-12, IL-17, IL-18, IL-21, IL-22 and IL-23) and other inflammatory molecules (sE-selectin, fibrinogen, C3) between psoriasis patients and healthy individuals.

The adipokines can play anti-inflammatory or proinflammatory roles in the systemic inflammation in psoriasis patients [74]. In inflammatory state underlying psoriasis, resistin produced mainly by monocytes and macrophages in adipose tissue, could stimulate the secretion of proinflammatory cytokines, TNF- $\alpha$ and IL-12, by monocytes in NF-kB-dependent manner. Resistin increases expression of adhesion molecules and production of chemokines in endothelial cells contributing to immune cells infiltration $[87,88]$. The expression of resistin is modulated by IL- $1 \beta$ and IL-6 [29, 73]. Chemerin, mainly produced by white adipose tissue, is also expressed by keratinocytes and endothelial cells [89-91]. Its production is increased by
IL1 $\beta$ and TNF- $\alpha$ [92-94]. Chemerin stimulates adipocytes and endothelial cells and may increase angiogenesis in psoriatic skin $[90,95,96]$. Chemerin can induce chemotaxis of plasmatoid dendritic cells (pDCs) and immature myeloid DCs in developing skin lesions of psoriasis patients [82].

Lipocalin-2, known as neutrophil gelatinaseassociated lipocalin, is a protein stored in the specific granules of human neutrophils [97]. It is regarded as an antimicrobial protein against bacterial infection by sequestrating iron [98]. The other well-established biologic functions of Lipocalin-2 include regulating diverse cellular processes, such as cell growth and migration/invasion [99-101]. In addition, Lipocalin-2 plays a role in the inflammation enhancing the production of pro-inflammatory cytokines including IL-6 and IL-8 [102]. Its expression can be induced by IL-17 [103]. Lipocalin-2 was expressed at a higher level in psoriatic skin that induced the secretion of pro-inflammatory factors and chemotaxis of neutrophils [104, 105]. However, its exact effect in the pathophysiology of psoriasis requires further study [36]. Visfatin is produced by adipose tissue, macrophages, dendritic cells and epithelial cells. It was shown to induce IL-1 $\beta$, TNF- $\alpha$, and IL- 6 production by monocytes [106]. Visfatin can promote the expression of a variety of inflammatory cytokines by keratinocytes in NF$\kappa B-d e p e n d e n t$ manner. Moreover, it can induce endothelial proliferation by upregulating the secretion of vascular endothelial growth factor in endothelial cells [83].

Adiponectin is produced by white adipose tissue, mainly by adipocytes [107-109]. It acts on various cell types including adipocytes, keratinocytes, monocytes, $\mathrm{T}$ lymphocytes, and endothelial cells. In general, adiponectin plays anti-inflammatory and protective roles. It was shown to inhibit production of pro-inflammatory cytokines like TNF- $\alpha$, IL-6, IL17 and to increase the production of anti-inflammatory factors including IL10 [110, 111]. In addition, adiponetin can suppress the vascular inflammation by inhibiting the expression of endothelial cell adhesion molecules (e.g. E-selectin) $[72,73,81]$. Omentin is produced in adipose tissue and its main producers are assumed to be endothelial cells $[112,113]$. It acts on adipocytes and endothelial cells. Similar to adiponectin, omentin plays anti-inflammatory role by suppressing TNF- $\alpha$-stimulated expression of proinflammatory factors in vascular endothelial cells [114]. Moreover, blood levels of omentin and adiponectin decreased in obesity [74].

We found that serum levels of three proinflamatory adipokines (chemerin, lipocalin-2 and resistin) were increased, while serum levels of one anti-inflammatory adipokine, adiponectin, were decreased in psoriasis patients. Contrary to what was expected, pooled serum levels of anti-inflammatory omentin were not significantly decreased in psoriasis patients. This could be due to only two included studies that in addition found opposite effects in the association of omentin levels with psoriasis. 
Omentin and adiponectin share anti-inflammatory properties. Moreover, plasma levels of omentin and adiponectin are positively correlated [115, 116]. More studies are needed to evaluate the association of blood levels of omentin with psoriasis.

Resistin and adiponectin could be potential biomarkers for the response to the anti-psoriatic treatment. Resistin was significantly increased in psoriasis patients (Figure 2, Supplementary Figure 22) and its plasma levels decreased upon anti-psoriatic treatment $[35,117,118]$. Adiponectin was significantly decreased in psoriasis patients (Figure 2, Supplementary Figure 18) and its plasma levels increased in response to anti-psoriatic treatment [119-122]. Previous studies have found that serum adipokine levels were positively related to PASI score, however our meta-analysis does not support it [31, 35]. In addition, our study showed that the differences were overall independent of age and gender.

In psoriasis, there is a cutaneous and systemic overexpression of various inflammatory cytokines and these cytokines could impact each other [4, 8, 9]. Once the cutaneous inflammation is stimulated by the antigen, macrophages, keratinocytes, Th1 cells, T17 cells, Th22 cells and BDCA-1-inflammatory DCs will produce TNF- $\alpha$, which plays an important role in the inflammatory process in psoriasis (Figure 4) [84]. TNF- $\alpha$ stimulates the migration of Langerhans cells by lowering the level of e-cadherin, and is involved in the NF- $\kappa \mathrm{B}$-mediated inflammation pathway, which contributes to cell survival, proliferation, and transcription of antiapoptotic factors [85]. Moreover, TNF- $\alpha$ can enhance the expression of IL-6, IL-8, C-reactive protein, which mediate T cell activation, the acute-phase inflammation reaction and provide a powerful signal for the concentration of neutrophils [86]. IFN- $\gamma$ is mainly produced by Th1 cells and can activate the signal transducer and activator of transcription (STAT) 1, which regulates many genes expressed in psoriatic skin lesions [84]. In addition, the transcription of IFN- $\gamma$ and TNF- $\alpha$ can be regulated by IL-2 and IL-12 [76]. IL-2 plays a role in the differentiation,

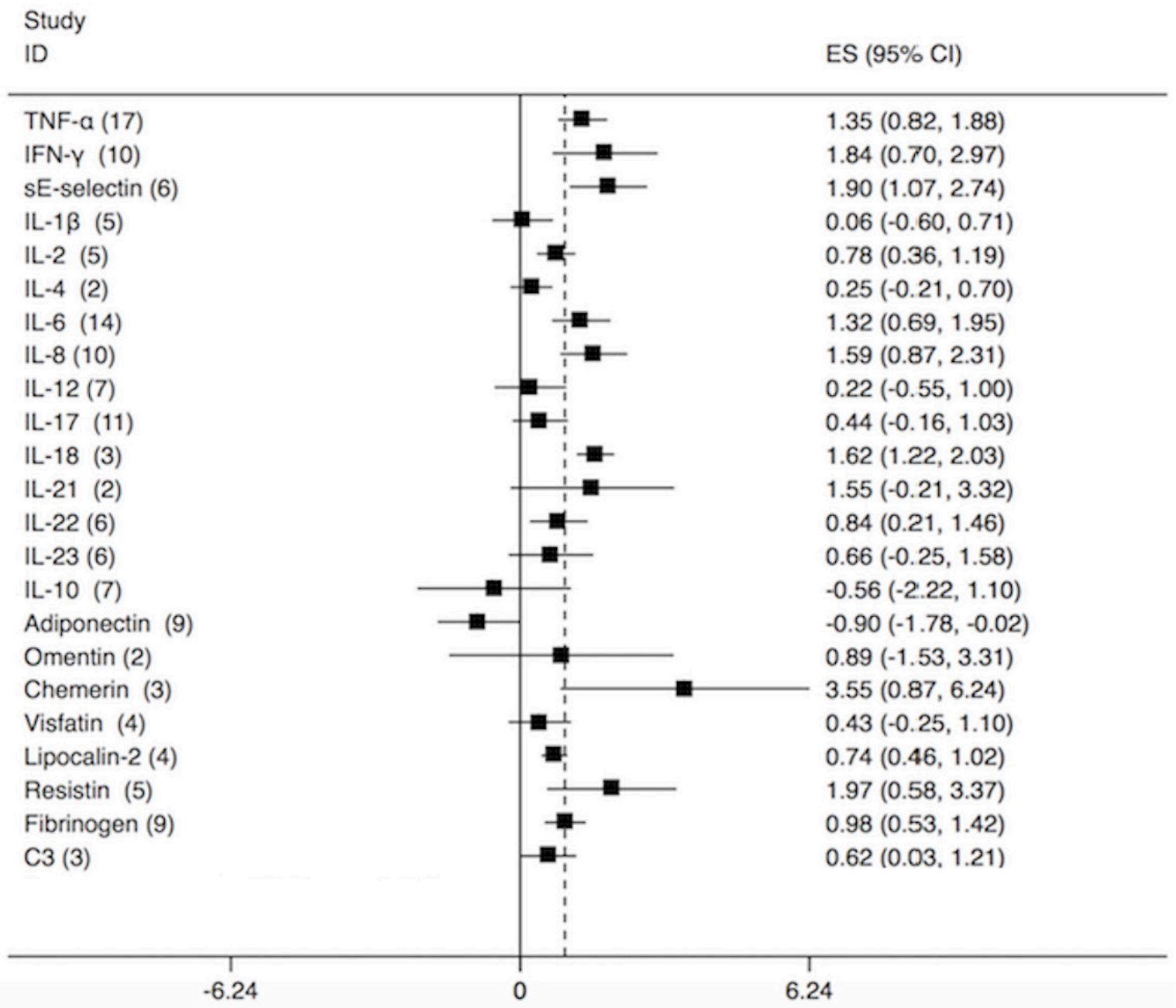

Figure 2: A forest plot of pooled standardized mean differences (SMDs) in serum levels of adipokines and cytokines. The diamond represents the exact estimate from the study. The width of the line extending from each diamond represents the $95 \%$ confidence interval (CI). All individual study data and forest plots for all individual cytokines and adipokines are detailed in the Supplementary Files. 
proliferation, and maturation of $\mathrm{T}$ cells into effector and memory T cells. IL-18 plays an important role in cell adhesion and can stimulate the release of IFN- $\gamma$ [86]. It is worth noting that IL-22 produced by Th17 and mainly Th22 cells has been observed to stimulate hyperplasia and abnormal differentiation of keratinocytes. In addition, TNF- $\alpha$, IL-1 $\beta$, IL- 6 , and INF- $\gamma$ have been found to increase the production of $\mathrm{C} 3$ from the liver and probably from adipose tissue in psoriasis patients. Fibrinogen is a multifunctional circulating glycoprotein involved in inflammation [23, 68, 77, 78]. IL-17 expression is activated by IL-23 and may be inhibited by IL-12. IL-17 has been shown to induce TNF- $\alpha$, IL-1 $\beta$, IL-6, IL-10 and IL-12. IL-21, produced by activated CD4+ T cells and NKT cells, can promote cell proliferation and mediation of cellular and humoral immunities [11].

The present meta-analysis found that TNF- $\alpha$, IFN- $\gamma$, sE-selectin, IL-2, IL-6, IL-8, IL-18, IL-22, fibrinogen and $\mathrm{C} 3$ were elevated in serum of patients with psoriasis, indicating that serum levels of these cytokines may correlate to their levels in tissue. Therefore, they could act as a novel biomarker to monitor disease occurence. In addition, our study found IL-17 as a risk factor for occurrence of psoriasis in men compared with women, but the mechanisms underlying the gender difference remains unclear.

\section{Study limitations}

Some potential limitations could affect the interpretation of our findings. First, we did not include the studies using interquartile ranges and medians. The sample size in these studies was not large, so the distribution of the data might not be symmetrical. Thus, the median was not similar to the mean and it was not possible to estimate a standard deviation from an interquartile range. Although, it limited the sample size, the pooled results might be more precise. Second, there was a significant heterogeneity between the included studies, which could reduce the reliability of our results. Therefore, stratified, sensitivity and meta-regression analyses were carried out to explore potential source of heterogeneity, which could strengthen our analysis. Third, the analysis was primarily based on unadjusted data and did not control for confounding factors including age, gender, and BMI, and therefore cannot exclude the influence of mixed factors. Several inflammatory adipokines and cytokines have been demonstrated to be associated with the pathogenesis of psoriasis in relation to BMI, which exerted a key role in development of psoriasis. We have performed metaregression analyses adjusted for age and gender, but not for BMI due to insufficient amount of available data. Finally,

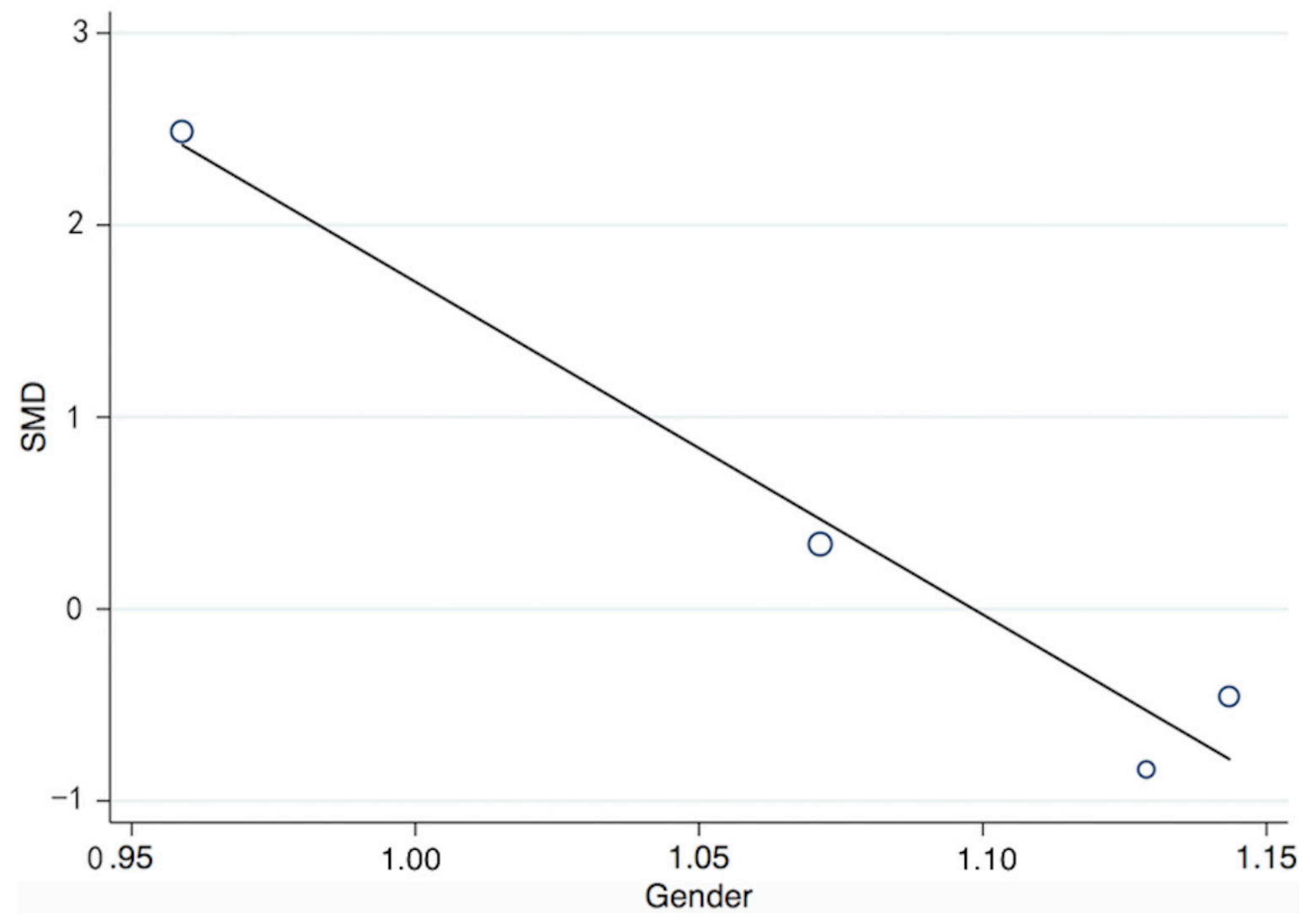

Figure 3: The meta-regression analysis for gender to assess differences in IL-17 serum levels between psoriasis patients and healthy controls. 
although apparent publication bias was not found using statistical tests, the potential publication bias could be a concern. It is challenging to completely rule out publication bias, and more studies are needed for its careful evaluation.

In conclusion, serum levels of TNF- $\alpha$, IFN- $\gamma$, IL-2, IL-6, IL-8, IL-18, IL-22, chemerin, lipocalin-2, resistin, sE-selectin, fibrinogen and C3 were significantly elevated and serum level of adiponectin was significantly decreased in psoriasis patients compared to healthy individuals. Our findings suggested that the difference was overall independent of age, gender, study quality and PASI, except gender difference observed in serum levels of IL17. The analyzed cytokines and adipokines can be used as markers for disease detection and to evaluate the efficacy of anti-psoriatic treatment. As serum levels of most of the analyzed factors are largely independent of psoriasis type and severity, they are unsuitable as markers to monitor disease progression. Future, carefully designed studies with large study populations are warranted to further evaluate the association of adipokines and cytokines serum levels with the pathogenesis of psoriasis.

\section{MATERIALS AND METHODS}

\section{Study identification}

This review was registered in PROSPERO (registration number: CRD 42017057297). Our metaanalysis was in accordance with the criteria for systematic reviews and meta-analyses [40].

A computer-based literature search was performed to identify the available relevant studies published before December 1, 2016 in PubMed, ScienceDirect and Web of Science, using the terms "IFN- $\gamma$ or TNF- $\alpha$ or sEselectin or IL- $1 \beta$ or IL- 2 or IL- 4 or IL- 6 or IL- 8 or IL-
10 or IL-12 or IL-17 or IL-18 or IL-21 or IL-22 or IL23 or adiponectin or omentin or chemerin or visfatin or resistin or fibrinogen or lipocalin-2 or C3" and "serum" and "psoriasis". The publication language was limited to English. The reference lists of retrieved articles were hand searched to find additional relevant studies.

\section{Study selection}

We determined inclusion and exclusion criteria before the search. The inclusion criteria were as follows: study design was limited to cross-sectional study, casecontrol study and cohort study; patients had to meet the diagnostic criteria for psoriasis; and the study provided the results as mean and standard deviation (SD) or original data to calculate mean and SD in a patient group and a control group. The exclusion criteria were as follows: the exposure included psoriatic arthritis; the study provided only the plasma biomarker concentration; the studies showed only median and interquartile range; and the psoriasis patients were under 18 years of age. If multiple publications reported results from the same study population, we included only the publication with the most subjects.

\section{Data abstraction and quality assessment}

Two independent investigators (F.B. and W.Z.) abstracted data using a standard data extraction form, and any disagreement was resolved by a third author (H.M.). The following information was extracted from each included article: first author, year of publication, study location, study design, number of cases and controls, psoriasis area and severity index (PASI), the mean age, male versus female proportion, ethnicity, psoriasis type, and the relevant serum biomarker level (mean $\pm \mathrm{SD}$ ).

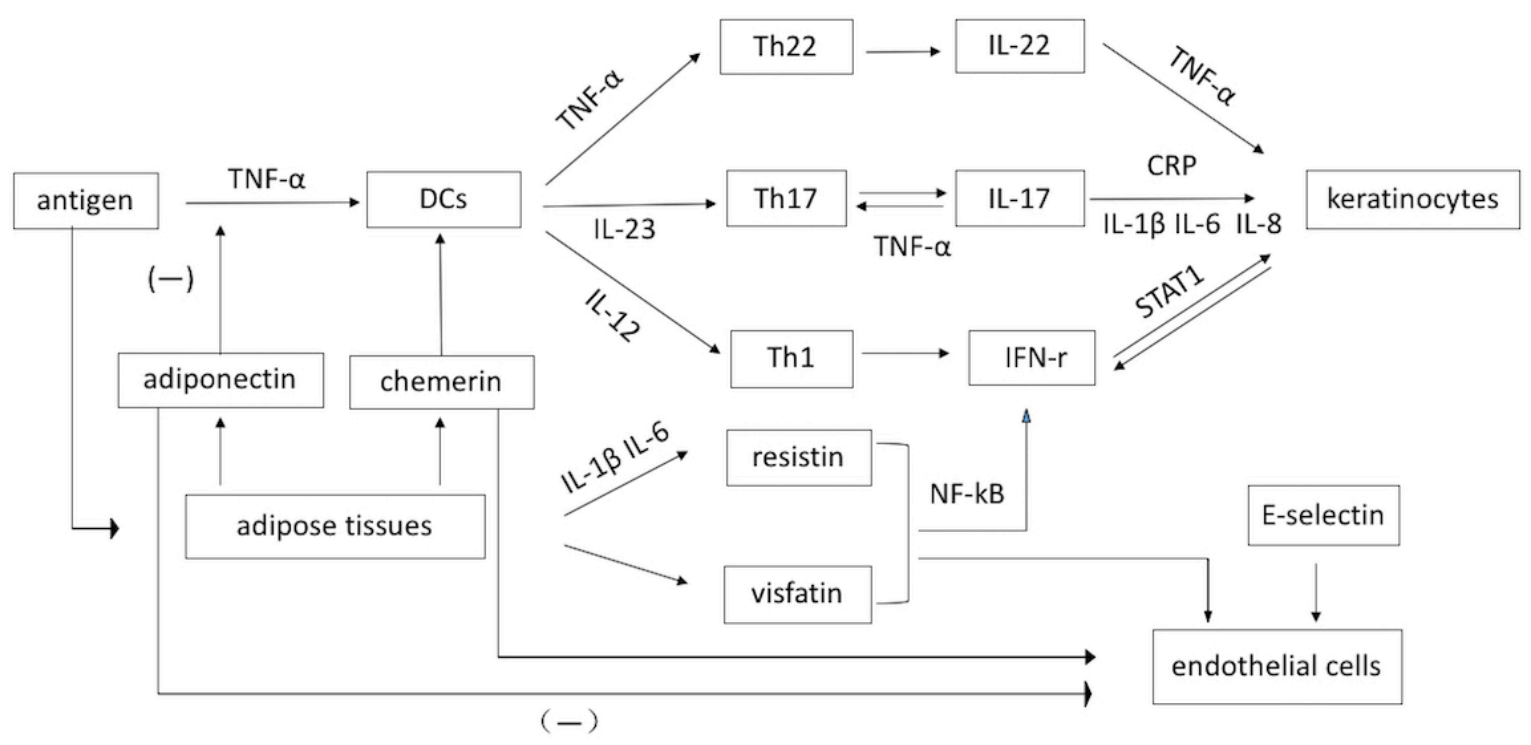

Figure 4: A schematic representation of role of the inflammatory factors in psoriasis. 
The study quality was assessed using the NewcastleOttawa Scale, categorized into three groups: the selection of the study groups (4 quality items), the comparability of the groups ( 2 items), and ascertainment of exposure (3 items). The scores ranged from 0 (the worst) to 9 (the best).

\section{Statistical analysis}

The expected outcome from each study was the difference in mean levels of serum marker between psoriasis patients and healthy controls. Because of differences in the measurement methods and units, standardized mean difference (SMD) with 95\% confidence intervals (CI) was calculated using Cohen's $\mathrm{d}$ in random-effects or fixed effects models. The between-study heterogeneity was evaluated by Q and I2 statistics. A random-effects model was used when the significant heterogeneity with $P<0.05$ or $\mathrm{I}^{2}>50 \%$ existed; otherwise, a fixed-effects model was chosen. To explore potential sources of heterogeneity, subgroup analysis was performed according to race (Caucasians vs. Asians), study design (Case control vs. Cross-sectional), and type of psoriasis (Psoriasis vulgaris vs. Others). We also conducted a meta-regression for age, gender, PASI and study quality score. In addition, a sensitivity analysis was performed to assess the stability of the pooled results by removing one study at a time. Publication bias was evaluated using Egger's regression test and Begg's adjusted rank correlation test $[79,80]$. All statistical analyses were carried out with Stata version 11.0 (STATA, College Station, TX, USA). $P$ value of $<0.05$ was considered statistically significant.

\section{Author contributions}

Conception and design of the study: H.M. and F.B. and J.A. Acquisition of data and analysis: J.W., Y.D., F.B., R.L., and W.Z. Writing and revision of the manuscript: M.A.G., F.B. and H.M. All authors read and approved the final manuscript.

\section{CONFLICTS OF INTEREST}

The authors declare no conflict of interest.

\section{FUNDING}

This study was partially supported by grants from the National Natural Science Foundation of China (NSFC81171503) and Xi'an Jiaotong University (1191329726, to M.A.G).

\section{REFERENCES}

1. Schön MP, Boehncke WH. Psoriasis. N Engl J Med. 2005; 352:1899-1912.
2. Kivelevitch D, Michel P, Menter A. Quality of life instruments in psoriasis clinical trials. Br J Dermatol. 2017; 176:563.

3. Michalek IM, Loring B, John SM. A systematic review of worldwide epidemiology of psoriasis. J Eur Acad Dermatol Venereol. 2017; 31:205-212.

4. Armstrong EJ, Krueger JG. Lipoprotein Metabolism and Inflammation in Patients with Psoriasis. Am J Cardiol. 2016; 118:603-609.

5. Libby P, Okamoto Y, Rocha VZ, Folco E. Inflammationin atherosclerosis: transition from theory to practice. Circ J. 2010; 74:213-220.

6. Ghazizadeh R, Shimizu H, Tosa M, Ghazizadeh M. Pathogenic mechanisms shared between psoriasis and cardiovascular disease. Int J Med Sci. 2010; 7:284-289.

7. Davidovici BB, Sattar N, Prinz J, Puig L, Emery P, Barker JN, van de Kerkhof P, Ståhle M, Nestle FO, Girolomoni G, Krueger JG. Psoriasis and systemic inflammatory diseases: potential mechanistic links between skin disease and comorbid conditions. J Invest Dermatol. 2010; 130:1785-1796.

8. Takahashi H, Tsuji H, Hashimoto Y, Ishida-Yamamoto A, Iizuka H. Serum cytokines and growth factor levels in Japanese patients with psoriasis. Clin Exp Dermatol. 2010; 35:645-649.

9. Choe YB, Hwang YJ, Hahn HJ, Jung JW, Jung HJ, Lee YW, Ahn KJ, Youn JI. A comparison of serum inflammatory cytokines according to phenotype in patients with psoriasis. Br J Dermatol. 2012; 167:762-727.

10. Alshorafa AK, Guo Q, Zeng F, Chen M, Tan G, Tang Z, Yin $\mathrm{R}$. Psoriasis is associated with low serum levels of hydrogen sulfide, a potential anti-inflammatory molecule. Tohoku J Exp Med. 2012; 228:325-332.

11. He Z, Jin L, Liu ZF, Hu L, Dang EL, Feng ZZ, Li QJ, Wang G. Elevated serum levels of interleukin 21 are associated with disease severity in patients with psoriasis. $\mathrm{Br} \mathrm{J}$ Dermatol. 2012; 167:191-193.

12. Kyriakou A, Patsatsi A, Vyzantiadis TA, Sotiriadis D. Serum levels of TNF- $\alpha$, IL-12/23p40, and IL-17 in plaque psoriasis and their correlation with disease severity. J Immunol Res. 2014; 2014:467541.

13. Baran A, Flisiak I, Jaroszewicz J, Swiderska M. Effect of psoriasis activity on serum adiponectin and leptin levels. Postepy Dermatol Alergol. 2015; 32:101-106.

14. Campanati A, Ganzetti G, Giuliodori K, Marra M, Bonfigli A, Testa R, Offidani A. Serum levels of adipocytokines in psoriasis patients receiving tumor necrosis factor- $\alpha$ inhibitors: results of a retrospective analysis. Int J Dermatol. 2015; 54:839-845.

15. Fotiadou C, Lazaridou E, Sotiriou E, Gerou S, Kyrgidis A, Vakirlis E, Ioannides D. IL-17A, IL-22, and IL-23 as Markers of Psoriasis Activity: A Cross-sectional, Hospitalbased Study. J Cutan Med Surg. 2015; 19:555-560.

16. Hayashi M, Yanaba K, Umezawa Y, Yoshihara Y, Kikuchi S, Ishiuji Y, Saeki H, Nakagawa H. IL-10-producing 
regulatory B cells are decreased in patients with psoriasis. J Dermatol Sci. 2016; 81:93-100.

17. Bilgic O, Sivrikaya A, Toker A, Unlu A, Altınyazar C. Serum levels of TWEAK in patients with psoriasis vulgaris. Cytokine. 2016; 77:10-13.

18. Xuan ML, Lu CJ, Han L, Xiang Y. Circulating levels of inflammatory cytokines in patients with psoriasis vulgaris of different Chinese medicine syndromes. Chin J Integr Med. 2015; 21:108-114.

19. Sereflican B, Goksugur N, Bugdayci G, Polat M, Haydar Parlak A. Serum Visfatin, Adiponectin, and Tumor Necrosis Factor Alpha (TNF- $\alpha$ ) Levels in Patients with Psoriasis and their Correlation with Disease Severity. Acta Dermatovenerol Croat. 2016; 24:13-19.

20. Coban M, Tasli L, Turgut S, Ozkan S, Tunç Ata M, Akın F. Association of Adipokines, Insulin Resistance, Hypertension and Dyslipidemia in Patients with Psoriasis Vulgaris. Ann Dermatol. 2016; 28:74-79.

21. Yilmaz SB, Cicek N, Coskun M, Yegin O, Alpsoy E. Serum and tissue levels of IL-17 in different clinical subtypes of psoriasis. Arch Dermatol Res. 2012; 304:465-469.

22. Akcali C, Buyukcelik B, Kirtak N, Inaloz S. Clinical and laboratory parameters associated with metabolic syndrome in Turkish patients with psoriasis. J Int Med Res. 2014; 42:386-394.

23. Torres $\mathrm{T}$, Bettencourt N, Mendonça D, Vasconcelos C, Silva BM, Selores M. Complement C3 as a marker of cardiometabolic risk in psoriasis. Arch Dermatol Res. 2014; 306:653-660.

24. Gkalpakiotis S, Arenbergerova M, Gkalpakioti P, Potockova J, Arenberger P, Kraml P. Impact of adalimumab treatment on cardiovascular risk biomarkers in psoriasis: Results of a pilot study. J Dermatol. 2017; 44:363-369.

25. Roh NK, Han SH, Youn HJ, Kim YR, Lee YW, Choe YB, Ahn KJ. Tissue and Serum Inflammatory Cytokine Levels in Korean Psoriasis Patients: A Comparison between Plaque and Guttate Psoriasis. Ann Dermatol. 2015; 27:738-743.

26. Zhou ZX, Chen JK, Hong YY, Zhou R, Zhou DM, Sun LY, Qin WL, Wang TC. Relationship Between the Serum Total Bilirubin and Inflammation in Patients with Psoriasis Vulgaris. J Clin Lab Anal. 2016; 30:768-775.

27. Dogan FB, Cicek D, Aydin S, Dertlioglu SB, Halisdemir N, Ucak H, Demir B, Erden I. Serum Preptin and Amylin Values in Psoriasis Vulgaris and Behçet's Patients. J Clin Lab Anal. 2016; 30:165-168.

28. Gerdes S, Osadtschy S, Rostami-Yazdi M, Buhles N, Weichenthal M, Mrowietz U. Leptin, adiponectin, visfatin and retinol-binding protein-4- mediators of comorbidities in patients with psoriasis? Exp Dermatol. 2012; 21:43-47.

29. Johnston A, Arnadottir S, Gudjonsson JE, Aphale A, Sigmarsdottir AA, Gunnarsson SI, Steinsson JT, Elder JT, Valdimarsson H. Obesity in psoriasis: leptin and resistin as mediators of cutaneous inflammation. Br J Dermatol. 2008; 159:342-350.
30. Shibata S, Saeki H, Tada Y, Karakawa M, Komine M, Tamaki K. Serum high molecular weight adiponectin levels are decreased in psoriasis patients. J Dermatol Sci. 2009; 55:62-63.

31. Kaur S, Zilmer K, Leping V, Zilmer M. The levels of adiponectin and leptin and their relation to other markers of cardiovascular risk in patients with psoriasis. J Eur Acad Dermatol Venereol. 2011; 25:1328-1333.

32. Nakajima H, Nakajima K, Tarutani M, Morishige R, Sano $\mathrm{S}$. Kinetics of circulating Th17 cytokines and adipokines in psoriasis patients. Arch Dermatol Res. 2011; 303:451-455.

33. Alobaidi A, Mothana Z, Najem W, Alsamarai A. Adiponectin, IL-10, IL-23 and trace element serum level in patients with psoriasis. Am J Clin Dermatol. 2012; 1:6-23.

34. Romaní J, Caixàs A, Ceperuelo-Mallafré V, Carrascosa JM, Ribera M, Rigla M, Vendrell J, Luelmo J. Circulating levels of lipocalin-2 and retinol-binding protein-4 are increased in psoriatic patients and correlated with baseline PASI. Arch Dermatol Res. 2013; 305:105-112.

35. Lora V, Bonaguri C, Gisondi P, Sandei F, Battistelli L, Russo A, Melegari A, Trenti T, Lippi G, Girolomoni G. Autoantibody induction and adipokine levels in patients with psoriasis treated with infliximab. Immunol Res. 2013; 56:382-389.

36. Ataseven A, Kesli R, Kurtipek GS, Ozturk P. Assessment of lipocalin 2, clusterin, soluble tumor necrosis factor receptor-1, interleukin-6, homocysteine, and uric acid levels in patients with psoriasis. Dis Markers. 2014; 2014:541709.

37. Elango $T$, Dayalan $H$, Subramanian S, Gnanaraj $P$, Malligarjunan H. Serum interleukin-6 levels in response to methotrexate treatment in psoriatic patients. Clin Chim Acta. 2012; 413:1652-1656.

38. Murakami M, Hagforsen E, Morhenn V, Ishida-Yamamoto A, Iizuka H. Patients with palmoplantar pustulosis have increased IL-17 and IL-22 levels both in the lesion and serum. Exp Dermatol. 2011; 20:845-847.

39. Michalak-Stoma A, Bartosińska J, Kowal M, JuszkiewiczBorowiec M, Gerkowicz A, Chodorowska G. Serum levels of selected Th17 and Th22 cytokines in psoriatic patients. Dis Markers. 2013; 35:625-31.

40. Zhang L, Yang XQ, Cheng J, Hui RS, Gao TW. Increased Th17 cells are accompanied by FoxP3(+) Treg cell accumulation and correlated with psoriasis disease severity. Clin Immunol. 2010; 135:108-117.

41. Jensen PR, Zachariae C, Hansen P, Skov L. Normal endothelial function in patients with mild-to-moderate psoriasis: a casecontrol study. Acta Derm Venereol. 2011; 91:516-520.

42. Abdel-Hamid MF, Aly DG, Saad NE, Emam HM, Ayoub DF. Serum levels of interleukin- 8 , tumor necrosis factor- $\alpha$ and $\gamma$-interferon in Egyptian psoriatic patients and correlation with disease severity. J Dermatol. 2011; 38:442-446.

43. Vanizor Kural B, Orem A, Cimşit G, Yandi YE, Calapoglu M. Evaluation of the atherogenic tendency of lipids and lipoprotein content and their relationships with oxidant- 
antioxidant system in patients with psoriasis. Clin Chim Acta. 2003; 328:71-82.

44. Anderson KS, Petersson S, Wong J, Shubbar E, Lokko NN, Carlström M, Enerbäck C. Elevation of serum epidermal growth factor and interleukin 1 receptor antagonist in active psoriasis vulgaris. Br J Dermatol. 2010; 163:1085-1089.

45. Gisondi P, Malerba M, Malara G, Puglisi Guerra A, Sala R, Radaeli A, Calzavara-Pinton P, Girolomoni G. C-reactive protein and markers for thrombophilia in patients with chronic plaque psoriasis. Int J Immunopathol Pharmacol. 2010; 23:1195-1202.

46. Arican O, Aral M, Sasmaz S, Ciragil P. Serum levels of TNF-alpha, IFN-gamma, IL-6, IL-8, IL-12, IL-17, and IL18 in patients with active psoriasis and correlation with disease severity. Mediators Inflamm. 2005; 2005:273-279.

47. Kamata M, Tada Y, Tatsuta A, Kawashima T, Shibata S, Mitsui H, Asano Y, Sugaya M, Kadono T, Kanda N, Watanabe S, Sato S. Serum lipocalin-2 levels are increased in patients with psoriasis. Clin Exp Dermatol. 2012; 37:296-299.

48. Arias-Santiago S, Orgaz-Molina J, Castellote-Caballero L, Arrabal-Polo MÁ, García-Rodriguez S, Perandrés-López R, Ruiz JC, Naranjo-Sintes R, Zubiaur M, Sancho J, BuendíaEisman A. Atheroma plaque, metabolic syndrome and inflammation in patients with psoriasis. Eur J Dermatol. 2012; 22:337-344.

49. Alpsoy S, Akyuz A, Erfan G, Akkoyun DC, Topcu B, Guzel S, Kaya S, Kulac M. Atherosclerosis, some serum inflammatory markers in psoriasis. G Ital Dermatol Venereol. 2014; 149:167-175.

50. Balta I, Balta S, Demirkol S, Mikhailidis DP, Celik T, Akhan M, Kurt O, Kurt YG, Aydin I, Kilic S. Elevated serum levels of endocan in patients with psoriasis vulgaris: correlations with cardiovascular risk and activity of disease. Br J Dermatol. 2013; 169:1066-1070.

51. El-Hadidi H, Samir N, Shaker OG, Otb S. Estimation of tissue and serum lipocalin-2 in psoriasis vulgaris and its relation to metabolic syndrome. Arch Dermatol Res. 2014; 306:239-245.

52. Borská L, Fiala Z, Krejsek J, Andrýs C, Vokurková D, Hamáková K, Kremlácek J, Ettler K. Selected immunological changes in patients with Goeckerman's therapy TNF-alpha, sE-selectin, sP-selectin, sICAM-1 and IL-8. Physiol Res. 2006; 55:699-706.

53. Czech W, Schöpf E, Kapp A. Soluble E-selectin in sera of patients with atopic dermatitis and psoriasis--correlation with disease activity. Br J Dermatol. 1996; 134:17-21.

54. De Pita O, Frezzolini A, Cianetti A, De Sanctis G, Fontana L, Bottari V. Squamous cell carcinoma-related antigen (SCCr-Ag), sICAM-1 and beta 2-microglobulin are useful markers of disease activity in psoriasis. Acta Derm Venereol. 1999; 79:132-135.

55. Gangemi S, Merendino RA, Guarneri F, Minciullo PL, DiLorenzo G, Pacor M, Cannavò SP. Serum levels of interleukin-18 and s-ICAM-1 in patients affected by psoriasis: preliminary considerations. J Eur Acad Dermatol Venereol. 2003; 17:42-46.

56. Jacob SE, Nassiri M, Kerdel FA, Vincek V. Simultaneous measurement of multiple Th1 and Th2 serum cytokines in psoriasis and correlation with disease severity. Mediators Inflamm. 2003; 12:309-313.

57. Kanda N, Ishikawa T, Kamata M, Tada Y, Watanabe S. Increased serum leucine, leucine-37 levels in psoriasis: positive and negative feedback loops of leucine, leucine-37 and pro- or anti-inflammatory cytokines. Hum Immunol. 2010; 71:1161-1171.

58. Jadali Z, Izad M, Eslami MB, Mansouri P. Th1/Th2 Cytokines in Psoriasis. Iranian Journal of Public Health. 2007; 36:87-91.

59. Karabudak O, Ulusoy RE, Erikci AA, Solmazgul E, Dogan B, Harmanyeri Y. Inflammation and hypercoagulable state in adult psoriatic men. Acta Derm Venereol. 2008; 88:337-340.

60. Laurent MR, Panayi GS, Shepherd P. Circulating immune complexes, serum immunoglobulins, and acute phase proteins in psoriasis and psoriatic arthritis. Ann Rheum Dis. 1981; 40:66-69.

61. Long JW, Tao J, Pi XM, Wang YY, Tu YT. Effect of Narrow-band UVB Phototherapy on Soluble Cell Adhesion Molecules in Patients with Psoriasis Vulgaris. J Int Med Res. 2010; 38:1507-1512.

62. Qiu S, Tan S, Zhang J, Liu P, Ran L, Lei X. Effect of liangxue huoxue xiaoyin tang on serum levels of TNFalpha, IFN-gamma and IL-6 in psoriasis of blood-heat type. J Tradit Chin Med. 2005; 25:292-295.

63. Rocha-Pereira P, Santos-Silva A, Rebelo I, Figueiredo A, Quintanilha A, Teixeira F. The inflammatory response in mild and in severe psoriasis. Br J Dermatol. 2004; 150:917-928.

64. Szegedi A, Aleksza M, Gonda A, Irinyi B, Sipka S, Hunyadi J, Antal-Szalmás P. Elevated rate of Thelper1 $(\mathrm{T}(\mathrm{H}) 1)$ lymphocytes and serum IFN-gamma levels in psoriatic patients. Immunol Lett. 2003; 86:277-380.

65. Szepietowski J, Wasik F, Bielicka E, Nockowski P, Noworolska A. Soluble E-selectin serum levels correlate with disease activity in psoriatic patients. Clin Exp Dermatol. 1999; 24:33-36.

66. Szepietowski JC, Bielicka E, Nockowski P, Noworolska A, Wasik F. Increased interleukin-7 levels in the sera of psoriatic patients: lack of correlations with interleukin-6 levels and disease intensity. Clin Exp Dermatol. 2000; 25:643-647.

67. Toruniowa B, Krasowska D, Kozioł M, Ksiazek A, Pietrzak A. Serum levels of IL-6 in mycosis fungoides, psoriasis, and lichen planus. Ann N Y Acad Sci. 1995; 762:432-434.

68. Vanizor Kural B, Orem A, Cimşit G, Uydu HA, Yandi YE, Alver A. Plasma homocysteine and its relationships with atherothrombotic markers in psoriatic patients. Clin Chim Acta. 2003; 332:23-30.

69. Kitamura T, Tamada Y, Kato M, Yokochi T, Ikeya T. Soluble E-selectin as a marker of disease activity in pustulosis palmaris et plantaris. Acta Derm Venereol. 1999; 79:462-464. 
70. Biasi D, Carletto A, Caramaschi P, Bellavite P, Maleknia T, Scambi C, Favalli N, Bambara LM. Neutrophil functions and IL-8 in psoriatic arthritis and in cutaneous psoriasis. Inflammation. 1998; 22:533-543.

71. Christophers E. The immunopathology of psoriasis. Int Arch Allergy Immunol. 1996; 110:199-206.

72. Gerdes S, Rostami-Yazdi M, Mrowietz U. Adipokines and psoriasis. Exp Dermatol. 2011; 20:81-87.

73. Wolk K, Sabat R. Adipokines in psoriasis: An important link between skin inflammation and metabolic alterations. Rev Endocr Metab Disord. 2016; 17:305-317.

74. Coimbra S, Catarino C, Santos-Silva A. The triad psoriasisobesity- adipokine profile. J Eur Acad Dermatol Venereol. 2016; 30:1876-1885.

75. Vachatova S, Andrys C, Krejsek J, Salavec M, Ettler K, Rehacek V, Cermakova E, Malkova A, Fiala Z, Borska L. Metabolic Syndrome and Selective Inflammatory Markers in Psoriatic Patients. J Immunol Res. 2016; 2016:5380792.

76. Pietrzak AT, Zalewska A, Chodorowska G, Krasowska D, Michalak-Stoma A, Nockowski P, Osemlak P, Paszkowski T, Roliński JM. Cytokines and anticytokines in psoriasis. Clin Chim Acta. 2008; 394:7-21.

77. Kopfnagel V, Wagenknecht S, Brand L, Zeitvogel J, Harder J, Hofmann K, Kleine M, Werfel T. RNase 7 downregulates TH2 cytokine production by activated human T-cells. Allergy. 2017. [Epub ahead of print]

78. Matsuura T, Sato M, Nagai K, Sato T, Arito M, Omoteyama K, Suematsu N, Okamoto K, Kato T, Soma Y, Kurokawa MS. Serum peptides as putative modulators of inflammation in psoriasis. J Dermatol Sci. 2017.

79. Begg CB, Mazumdar M. Operating characteristics of a rank correlation test for publication bias. Biometrics. 1994; 50:1088-1101.

80. Song F, Gilbody S. Bias in meta-analysis detected by a simple, graphical test. Increase in studies of publication bias coincided with increasing use of meta-analysis. BMJ. 1998; 316:471.

81. López-Jaramillo P, Gómez-Arbeláez D, López-López J, López-López C, Martínez-Ortega J, Gómez-Rodríguez A, Triana-Cubillos S. The role of leptin/adiponectin ratio in metabolic syndrome and diabetes. Horm Mol Biol Clin Investig. 2014; 18:37-45.

82. Bondue B, Wittamer V, Parmentier M. Chemerin and its receptors in leukocyte trafficking, inflammation and metabolism. Cytokine Growth Factor Rev. 2011; 22:331-338.

83. Adya R, Tan BK, Punn A, Chen J, Randeva HS. Visfatin induces human endothelial VEGF and MMP-2/9 production via MAPK and PI3K/Akt signalling pathways: novel insights into visfatin-induced angiogenesis. Cardiovasc Res. 2008; 78:356-365.

84. Mahil SK, Capon F, Barker JN. Update on psoriasis immunopathogenesis and targeted immunotherapy. Semin Immunopathol. 2016; 38:11-27.

85. Kupetsky EA, Mathers AR, Ferris LK. Anti-cytokine therapy in the treatment of psoriasis. Cytokine. 2013; 61:704-712.
86. Coimbra S, Figueiredo A, Castro E, Rocha-Pereira P, SantosSilva A. The roles of cells and cytokines in the pathogenesis of psoriasis. Int J Dermatol. 2012; 51:389-398.

87. Verma S, Li SH, Wang CH, Fedak PW, Li RK, Weisel RD, Mickle DA. Resistin promotes endothelial cell activation: further evidence of adipokine-endothelial interaction. Circulation. 2003; 108:736-740.

88. Cho Y, Lee SE, Lee HC, Hur J, Lee S, Youn SW, Lee J, Lee HJ, Lee TK, Park J, Hwang SJ, Kwon YW, Cho HJ, et al. Adipokine resistinis a key player to modulate monocytes, endothelial cells, and smoot muscle cells, leading to progression of atherosclerosis in rabbit carotidartery. J Am Coll Cardiol. 2011; 57:99-109.

89. Bozaoglu K, Bolton K, McMillan J, Zimmet P, Jowett J, Collier G, Walder K, Segal D. Chemerin is a novel adipokine associated with obesity and metabolic syndrome. Endocrinology. 2007; 148:4687-4694.

90. Goralski KB, McCarthy TC, Hanniman EA, Zabel BA, Butcher EC, Parlee SD, Muruganandan S, Sinal CJ. Chemerin. A novel adipokine that regulates adipogenesis and adipocyte metabolism. J Biol Chem. 2007; 282:28175-28188.

91. Wittamer V, Franssen JD, Vulcano M, Mirjolet JF, Le Poul E, Migeotte I, Brézillon S, Tyldesley R, Blanpain C, Detheux M, Mantovani A, Sozzani S, Vassart G, et al. Specific recruitment of antigen-presenting cells by chemerin, a novel processed ligand from human inflammatory fluids. J Exp Med. 2003; 198:977-985.

92. Kralisch S, Weise S, Sommer G, Lipfert J, Lossner U, Bluher M, Stumvoll M, Fasshauer M. Interleukin-1beta induces the novel adipokine chemerin in adipocytes in vitro. Regul Pept. 2009; 154:102-106.

93. Parlee SD, Ernst MC, Muruganandan S, Sinal CJ, Goralski KB. Serum Chemerin Levels Vary with Time of Day and Are Modified by Obesity and Tumor Necrosis Factor- $\alpha$. Endocrinology. 2010; 151:2590-2602.

94. Sell H, Laurencikiene J, Taube A, Eckardt K, Cramer A, Horrighs A, Arner P, Eckel J. Chemerin is a novel adipocytederived factor inducing insulin resistance in primary human skeletal muscle cells. Diabetes. 2009; 58:2731-2740.

95. Bozaoglu K, Curran JE, Stocker CJ, Zaibi MS, Segal D, Konstantopoulos N, Morrison S, Carless M, Dyer TD, Cole SA, Goring HH, Moses EK, Walder K, et al. Chemerin, a Novel Adipokine in the Regulation of Angiogenesis. J Clin Endocrinol Metab. 2010; 95:2476-2485.

96. Kaur J, Adya R, Tan BK, Chen J, Randeva HS. Identification of chemerin receptor (ChemR23) in human endothelial cells: chemerin-induced endothelial angiogenesis.Biochem Biophys Res Commun. 2010; 391:1762-1768.

97. Kjeldsen L, Bainton DF, Sengeløv H, Borregaard N. Identification of neutrophil gelatinase-associated lipocalin as a novel matrix protein of specific granules in human neutrophils. Blood. 1994; 83:799-807.

98. Flo TH, Smith KD, Sato S, Rodriguez DJ, Holmes MA, Strong RK, Akira S, Aderem A. Lipocalin 2 mediates 
an innate immune response to bacterial infection by sequestrating iron. Nature. 2004; 432:917-921.

99. Ding G, Fang J, Tong S, Qu L, Jiang H, Ding Q, Liu J. Over-expression of lipocalin 2 promotes cell migration and invasion through activating ERK signaling to increase SLUG expression in prostate cancer. Prostate. 2015; 75:957-968.

100. Nelson AM, Zhao W, Gilliland KL, Zaenglein AL, Liu W, Thiboutot DM. Neutrophil gelatinase-associated lipocalin mediates 13-cis retinoic acid-induced apoptosis of human sebaceous gland cells. J Clin Invest. 2008; 118:1468-1478.

101. Wang G, Weng YC, Han X, Whaley JD, McCrae KR, Chou WH. Lipocalin-2 released in response to cerebral ischaemia mediates reperfsion injury in mice. J Cell Mol Med. 2015; 19:1637-1645.

102. Lin HH, Liao CJ, Lee YC, Hu KH, Meng HW, Chu ST. Lipocalin-2 induced cytokine production enhances endometrial carcinoma cell survival and migration. Int $\mathrm{J}$ Biol Sci. 2011; 7:74-86.

103. Ferreira MC, Whibley N, Mamo AJ, Siebenlist U, Chan YR, Gaffen SL. Interleukin-17-induced protein lipocalin 2 is dispensable for immunity to oral candidiasis. Infect Immun. 2014; 82:1030-1035.

104. Seo SJ, Ahn JY, Hong CK, Seo EY, Kye KC, Lee WH, Lee SK, Lim JS, Hahn MJ, Kjeldsen L, Borregaard N, Kim CD, Park JK, Lee JH. Expression of neutrophil gelatinaseassociated lipocalin in skin epidermis. J Invest Dermatol. 2006; 126:510-512.

105. Shao S, Cao T, Jin L, Li B, Fang H, Zhang J, Zhang Y, $\mathrm{Hu}$ J, Wang G. Increased Lipocalin-2 Contributes to the Pathogenesis of Psoriasis by Modulating Neutrophil Chemotaxis and Cytokine Secretion. J Invest Dermatol. 2016; 136:1418-1428.

106. Moschen AR, Kaser A, Enrich B, Mosheimer B, Theurl M, Niederegger H, Tilg H. Visfatin, an adipocytokine with proinflammatory and immunemodulating properties. J Immunol. 2007; 178:1748-1758.

107. Hu E, Liang P, Spiegelman BM. AdipoQ is a novel adiposespecific gene dysregulated in obesity. J Biol Chem. 1996; 271:10697-10703.

108. Maeda K, Okubo K, Shimomura I, Funahashi T, Matsuzawa Y, Matsuara K. cDNA cloning and expression of a novel adipose specific collagen-like factor, apM1 (adipose most abundant gene transcript 1). Biochem Biophys Res Commun. 2012; 425:556-559.

109. Fain JN, Madan AK, Hiler ML, Cheema P, Bahouth SW. Comparison of the release of adipokines by adipose tissue, adipose tissue matrix, and adipocytes from visceral and subcutaneous abdominal adipose tissues of obese humans. Endocrinology. 2004; 145:2273-2278.

110. Campfield LA, Smith FJ, Guisez Y, Devos R, Burn P. Recombinant mouse OB protein: evidence for a peripheral signal linking adiposity and central neural networks. Science. 1995; 269:546-549.
111. Shibata S, Tada Y, Hau CS, Mitsui A, Kamata M, Asano Y, Sugaya M, Kadono T, Masamoto Y, Kurokawa M, Yamauchi T, Kubota N, Kadowaki T, Sato S. Adiponectin regulates psoriasiform skin inflammation by suppressing IL-17 production from $\gamma \delta$-T cells. Nat Commun. 2015; 6:7687.

112. Yang RZ, Lee MJ, Hu H, Pray J, Wu HB, Hansen BC, Shuldiner AR, Fried SK, McLenithan JC, Gong DW. Identification of omentin as a novel depot-specific adipokine in human adipose tissue:possible role in modulating insulin action. Am J Physiol Endocrinol Metab. 2006; 290:1253-1261.

113. Lee JK, Schnee J, Pang M, Wolfert M, Baum LG, Moremen KW, Pierce M. Human homologs of the Xenopus oocyte cortical granule lectin XL35. Glycobiology. 2001; 11:65-73.

114. Yamawaki H, Kuramoto J, Kameshima S, Usui T, Okada M, Hara Y. Omentin, a novel adipocytokine inhibits TNFinduced vascular inflammation in human endothelial cells. Biochem Biophys Res Commun. 2011; 408:339-343.

115. de Souza Batista CM, Yang RZ, Lee MJ, Glynn NM, Yu DZ, Pray J, Ndubuizu K, Patil S, Schwartz A, Kligman M, Fried SK, Gong DW, Shuldiner AR, et al. Omentin plasma levels and gene expression are decreased in obesity. Diabetes. 2007; 56:1655-1661.

116. Pan HY, Guo L, Li Q. Changes of serum omentin-1 levels in normal subjects and in patients with impaired glucose regulation and with newly diagnosed and untreated type 2 diabetes. Diabetes Res Clin Pract. 2010; 88:29-33.

117. Boehncke WH, Gladman DD, Chandran V. Cardiovascular comorbidities in psoriasis and psoriatic arthritis: pathogenesis, consequences for patient management, and future research agenda: a report from the GRAPPA 2009 annual meeting. J Rheumatol. 2011; 38:567-671.

118. Gisondi P, Lora V, Bonauguri C, Russo A, Lippi G, Girolomoni G. Serumchemerin is increased in patients with chronic plaque psoriasis and nor-malizes following treatment with infliximab. Br J Dermatol. 2013; 168:749-755.

119. Rajappa M, Rathika S, Munisamy M, Chandrashekar L, Thappa DM. Effect of treatment with methotrexate and coal tar on adipokine levels and indices of insulin resistance and sensitivity in patients with psoriasis vulgaris. J Eur Acad Dermatol Venereol. 2015; 29:69-76.

120. Coimbra S, Oliveira H, Reis F, Belo L, Rocha S, Quintanilha A, Figueiredo A, Teixeira F, Castro E, RochaPereira P, Santos-Silva A. Circulating adipokine levels in Portuguese patients with psoriasis vulgaris according to body mass index, severity and therapy. J Eur Acad Dermatol Venereol. 2010; 24:1386-1394.

121. Schmieder A, Poppe M, Hametner C, Meyer-Schraml H, Schaarschmidt ML, Findeisen P, Benoit S, Bauer B, Schmid S, Goebeler M, Goerdt S, Ludwig-Peitsch WK. Impact of fumaric acid esters on cardiovascular risk factors and depression in psoriasis: a prospective pilot study. Arch Dermatol Res. 2015; 307:413-424.

122. Shibata S, Tada Y, Hau C, Tatsuta A, Yamamoto M, 
Kamata M, Karakawa M, Asano Y, Mitsui H, Sugaya M, Kadono T, Saeki H, Kanda N, Sato S. Adiponectin as an anti-inflammatory factor in the pathogenesis of psoriasis: induction of elevated serum adiponectin levels following therapy. Br J Dermatol. 2011; 164:667-670.
123. Dowlatshahi EA, van der Voort EA, Arends LR, Nijsten T. Markers of systemic inflammation in psoriasis: a systematic review and meta-analysis. Br J Dermatol. 2013; 169:266-282. 